\title{
KOMITMEN UNIT PELAKSANA TEKNIS DAERAH KOTA MANADO PADA PENANGANAN KELUHAN PELAYANAN PAJAK KENDARAAN BERMOTOR
}

\author{
Shirley Y. V. I. Goni \\ Jurusan Sosiologi, Fakultas Ilmu Sosial dan Politik Universitas Sam Ratulangi \\ E-mail: shirleygoni@ymail.com.Hp.081340052225
}

\begin{abstract}
ABSTRAK. Keluhan masyarakat dalam pengurusan administrasi kendaraan bermotor secara umum terjadi karena beberapa hal yang antara lain organisasi pelayanan gagal mewujudkan kinerja yang dijanjikan. Memperhatikan berbagai keluhan, maka sebagai organisasi pemberi layanan sangat penting meresponi berbagai keluhan guna dijadikan sebagai komitmen dalam perbaikan kinerja dan memperbaiki pelayanan menujuh ke arah yang lebih baik. Untuk hal tersebut maka penelitian ini berupaya menjelaskan komitmen penanganan keluhan pelayanan pajak kendaraan bermotor oleh Kantor Sistem Administrasi Manunggal Satu Atap Unit Pelaksana Teknis Daerah Kota Manado bagi pengembangan ilmu sosial humaniora. Dengan menggunakan desain deskriptif kualitatif penelitian ini menekankan bahwa komitmen penanganan keluhan belum sepenuhnya nyata dijalankan pada pelayanan pajak kendaraan bermotor di Kantor Sistem Administrasi Manunggal Satu Atap Unit Pelaksana Teknis Daerah Kota Manado karena pengembangan kinerja pegawai lebih menekankan pada terwujudnya Pendapatan Asli Daerah sebagai sumber utama Anggaran Pendapatan Belanja Daerah bukan pada peningkatan kualitas pelayanan. Olehnya perlu dilakukan dengan cara perbaikan pada pengembangan kinerja pegawai yang mencakup perbaikan pada menyusun visi, misi dan rencana organisasi, tindakan pelaksanaan, pengawasan jalannya dan hasil pekerjaan, evaluasi atas kemajuan serta kegagalan organisasi, sistem karier, kompetensi, kompensasi dan motivasi kerja
\end{abstract}

Kata kunci: Komitmen, Penanganan Keluhan, Pelayanan.

ABSTRACT. Public complaints in administrative proceedings motor vehicles generally occur for several reasons, among others, service organizations failed to deliver the promised performance. Noting the wide range of complaints, it is a very important service organizations to respond to complaints in order to serve as a commitment to performance improvement and repair services menujuh to a better direction. For that matter, this study seeks to explain the commitment of complaint handling motor vehicle tax services by the Office of Administrative System Manunggal One Roof Regional Technical Implementation Unit of Manado for the development of social sciences and humanities.By using descriptive qualitative study emphasizes that the commitment to the handling of complaints has not completely real run at the service of motor vehicle taxes in Office Administration System Manunggal One Roof Regional Technical Implementation Unit of Manado for the development of employee performance is more emphasis on the realization of local revenue as the main source of budget revenues Local shopping is not on improving service quality. By it need to be done by way of improvement in employee performance development which includes improvements to the develop a vision, mission and organizational plan, action implementation, monitoring the course and results of the work, evaluation of progress and the failure of the organization, career system, competencies, compensation and motivation

Keywords: Commitment, Complaint Handling, Service.

\section{PENDAHULUAN}

Pelayanan yang berfokus pada customer (masyarakat) tidak hanya dengan memperhatikan hal-hal apa saja yang menjadi kebutuhan dan harapan masyarakat, namun juga memperhatikan dan memberikan perhatian pada keluhan (pengaduan) yang datang dari masyarakat. Keluhan merupakan pernyataan ketidakpuasan, apapun bentuknya (tertulis maupun lisan) tentang pelayanan, tindakan dan/atau kekurangan tindakan yang dilakukan oleh instansi penyedia pelayanan atau para stafnya yang mempengaruhi atau dirasakan oleh para pengguna pelayanan tersebut.

Sebenarnya kita dapat berpikir positif dan menganggap keluhan sebagai umpan balik guna meningkatkan kualitas pelayanan bahwa dengan adanya keluhan merupakan suatu tantangan yang dapat diubah menjadi kesempatan untuk membuktikan kehandalan dan kecakapan dalam rangka mengubah kondisi ketidakpuasan menjadi kepuasan bahkan dapat dijadikan sebagai daya dorong dalam memperbaiki kinerja personal mapun lembaga dalam menjalankan program kegiatan maupun produk yang dapat dirasakan dampaknya oleh masyarakat secara luas.

Adanya keluhan dalam satu sisi merupakan alat kendali atau evaluasi terhadap pemberian kualitas pelayanan yang selama ini diberikan kepada masyarakat. Namun pada sisi lain adalah suatu hal yang perlu diperhatikan, yang menjadikan keluhan sebagai suatu masalah yang perlu dicari solusinya. Penanganan terhadap munculnya keluhan harus ditanggapi secara rasional dan sebaiknya mengeliminir faktor emosional. Sesungguhnya apabila terjadi keluhan sulit untuk membedakan sifat dari yang dikeluhkan yang biasanya keluhan berupa masalah yang serius.

Pengaduan atau komplain secara umum muncul terlihat oleh karena beberapa hal yang antara lain organisasi pelayanan gagal mewujudkan kinerja yang dijanjikan, pelayanan yang tidak efisien, pelayanan yang diberikan secara kasar atau tidak membantu, gagal menyampaikan info perubahan kepada pelanggan atau masyarakat, banyaknya pelayanan yang tertunda, 
ketidaksopanan ketidakramahan aparat pelayanan, pelayanan yang tidak layak atau tidak wajar, aparat pelayanan yang tidak kompeten, aparat pelayanan yang apatis / tidak adanya atensi maupun organisasi pelayanan tidak responsif terhadap kebutuhan dan keinginan serta harapan pelanggan yang dimana hal ini terlihat dalam pelayanan pajak kendaraan bermotor di Kantor Sistem Administrasi Manunggal Satu Atap Unit Pelaksana Teknis Daerah Kota Manado.

Menjadi penting untuk memperhatikan pengaduan dari masyarakat karena adanya keluhan dalam satu sisi merupakan alat kendali atau evaluasi terhadap pemberian kualitas pelayanan yang selama ini diberikan kepada masyarakat. Namun juga sebagai suatu masalah yang perlu dicari solusinya. Penanganan terhadap munculnya keluhan harus ditanggapi secara rasional dan sebaiknya mengeliminir faktor emosional. Keluhan masyarakat dalam pengurusan administrasi kendaraan bermotor bersumber dari kesemrautan pelayanan seperti saat melakukan pendaftaran dimana loket pelayanan tersedia namun pendaftaran tidak dilakukan di loket akan tetapi langsung kepada oknum-oknum tertentu yang adalah merupakan pegawai yang dalam perilaku menunjukkan seperti calo pendaftaran. Demikian pulah dengan ketidak sesuaian perhitungan biaya, kepastian waktu penyelesaian tergantung besaran biaya tambahan yang diberikan. Permasalahan lainnya yaitu sering terjadinya kehabisan bahan baku, pelayanan yang lambat dengan berbagai macam alasan, dan drive true yang tidak berfungsi.

Memperhatikan berbagai keluhan dalam pelayanan pajak kendaraan bermotor yang berkaitan dengan prosedur, persyaratan, petugas, kecepatan pelayanan, keadilan, keramahan biaya, kenyamanan dan keamanan, maka sangat penting bagi Kantor Sistem Administrasi Manunggal Satu Atap Unit Pelaksana Teknis Daerah Kota Manado ketika meresponi berbagai keluhan yang dikemukakan oleh masyarakat selaku penerima layanan sebab merupakan alat kontrol bagi perbaikan kerja kantor sendiri. Respon yang ditunjukkan oleh organisasi pelaksana menunjukan adanya komitmen dalam memperbaiki pelayanan menujuh ke arah yang lebih baik.

Keluhan diartikan sebagai sesuatu yang tidak menyenangkan atau keluhan sebagai suatu ungkapan kurang puas akan produk atau pelayanan baik lisan maupun tulisan dari pelanggan internal dan ekseternal (LAN, 2006 :14), yang oleh Gorton (2005 :2) Complaints are a vital form of consumer feedback that provides unique and valuable information to an organisation concerned with quality improvement and risk management. Untuk meresponei berbagai keluhan masyarakat diperlukannya suatu komitmen yang nyata dari pihak Kantor Sistem Administrasi Manunggal Satu Atap Unit Pelaksana Teknis Daerah Kota Manado baik unsup pimpinan maupun staf.

Luthans (2008:147) mendefinisikan komitmen sebagai: “(1) a strong desire to remain a member of particular organization; (2) a willingness to exert hight levels of effort on behalf of the organization; and (3) a definite belive in, an acceptance of, the values and goals of the organization". Komitmen sebagai suatu bentuk dari perasaan yang ditimbulkan sebagai akibat dari keinginan-keinginan yang kuat seseorang sebagai bagian dari anggota organisasi, yang mempunyai keinginan kuat dalam bekerja, serta mampu memenuhi kebutuhan organisasi, juga memiliki keyakinan yang kuat pada penerimaan dan penetapan tujuan organisasi. Dalam kaitannya dengan keluhan public, Gorton (2005) Commitment - The health service and its senior management are fully committed to an integrated complaints management system and will provide the necessary support for it to operate effectively. Komitmen dipandang penting dalam suatu organisasi, karena dengan komitmen yang tinggi seorang pegawai akan bersikap profesional dan menjunjung tinggi nilai-nilai yang telah disepakati bersama dalam organisasi, yang fokusnya adalah nilai-nilai dan sikap yang dimiliki oleh pegawai.

Penelitian yang dilakukan oleh Boshoff dan Mels (1995), Hanneke Heinsmen dkk., (2008), Herman Darwis (2005) menunjukkan pentingnya komimen dalam sebuah organisasi yang memberikan kontribusi bagi pencapaian kinerja maupun perbaikan kualitas pelayanan. Komitmen diartikan sebagai kemauan dan penerimaan seseorang. Seorang individu mau bekerja keras untuk objek, sasaransasaran dan nilai-nilai tertentu, atau dia ingin menjadi anggota dalam sebuah sistem sosial (aspek sosial). Sebuah organisasi menjadi lebih menarik atau kurang menarik sangat tergantung kepada tenaga kerja potensial. Seorang individu mungkin memiliki keterlibatan yang tinggi dalam pekerjaan mereka (memiliki kasih sayang psikologis), yang berarti "melakukan apa saja yang dapat dilakukan untuk menyelesaikan pekerjaan" (Brown dalam Herman Darwis, 2005:30).

Merupakan suatu yang urgent untuk diperhatikan dewasa ini karena dalam pelayanan publik terdapat hak masyarakat untuk menyampaikan keluhan atau masukan atas pelayanan yang diterima apabila para pelaksana dan penyelenggara melakukan penyimpangan standar pelayanan. Selain itu, masyarakat juga berhak untuk memperoleh tanggapan atas pengaduannya. Hal ini sebagaimana yang diatur di dalam UU Nomor 25 Tahun 2009 tentang Pelayanan Publik Pasal 18 ayat (c) bahwa masyarakat berhak mendapatkan tanggapan terhadap pengaduan yang diajukan.

Melakukan pengaduan adalah menjadi hak masyarakat yang wajib mereka gunakan untuk memperoleh apa yang mereka harapkan dari pelayanan, dan di lain pihak menerima dan mengolah pengaduan juga menjadi kewajiban pemerintah atau penyelenggara pelayanan sebagai bagian dari upaya untuk memperbaiki kualitas pelayanan. Komitmen dalam penanganan atas keluhan yang belum diresponi dengan baik sehingga belum ada perbaikan yang berarti dalam pelayanan sebagaimana harapan masyarakat. Menjadi tangung jawab organisasi untuk memiliki komitmen dalam melayani pengaduan sehingga memberikan dampak yang berarti bagi perbaikan pelayanan. Untuk hal tersebut maka 
penelitian ini berupaya menjelaskan komitmen penanganan keluhan pelayanan pajak kendaraan bermotor di Kantor Sistem Administrasi Manunggal Satu Atap Unit Pelaksana Teknis Daerah Kota Manado bagi pengembangan ilmu sosial humaniora.

\section{METODE PENELITIAN}

Berangkat dari tujuan penelitian untuk mengungkapkan komitmen penanganan keluhan pelayanan pajak kendaraan bermotor di Kantor Sistem Administrasi Manunggal Satu Atap Unit Pelaksana Teknis Daerah Kota Manado maka desain penelitian ini menggunakan metode kualitatif. Pertimbangan digunakannya metode penelitian kualitatif dimaksudkan untuk menemukan dan memahami apa yang ada di balik fenomena yang akan diteliti. Pemilihan pendekatan kualitatif untuk menjawab masalah penelitian yang diajukan dengan menekankan pada interprestasi bukan pada generalisasi dan lebih kepada mengungkap meaning dan memahami fenomena komitmen penanganan keluhan pelayanan pajak kendaraan bermotor.

Pilihan pada pendekatan kualitatif dengan argumentasi bahwa kualitatif dapat membantu interpretasi hubungan antara ubahan serta relatif dapat mengungkap alasan bagi hubungan tersebut. Selain itu kualitatif lebih dapat menyentuh secara mendalam aspek behavioral skala kecil, lebih dapat mengungkap rincian kompleks tentang fenomena lapangan. Dengan demikian diharapkan lahirnya preposisi hipotetik baru melalui intrepretasi interaksi antara atribut dan properties yang selanjutnya dapat digunakan untuk membangun kategori dan memberikan eksplanasi terhadap fenomena yang diteliti.

\section{HASIL DAN PEMBAHASAN}

Komitmen menjadi suatu faktor penting yang harus dimiliki dalam menjalani hidup ini terlebih dalam tugas tanggung jawab khusus yang diberikan. Secara sederhana dapat dikatakan bahwa komitmen sebagai suatu kesediaan untuk bertahan pada rencana dan kesepakatan semula walaupun keadaan semakin tak menentu. Keluhan muncul oleh karena adanya sesuatu yang dirasakan yang dianggap tidak sesuai dengan yang diharapkan.

Keluhan dalam pelayanan pajak kendaraan bermotor baik lambannya pelayanan, pungutan yang tidak sesuai sampai pada proses yang berbelit belit menjadi suara sumbang yang selalu di ungkapkan oleh masyarakat penerima layanan. Satu dari lima tujuan Dinas Pendapatan Daerah Provinsi Sulawesi Utara yang adalah juga melekat pada Kantor Sistem Administrasi Manunggal Satu Atap Unit Pelaksana Teknis Daerah Kota Manado sesuai dengan misi "Meningkatkan pelayanan kepada masyarakat" yang tujuannya adalah : terwujudnya pelayanan yang cepat, aman, mudah, murah dan ramah bagi masyarakat.

Mencermati penjabaran tujuan dinas berkaitan dengan misi untuk terwujudnya pelayanan yang cepat, aman, mudah, murah dan ramah bagi masyarakat setidaknya perlu menjadi komitmen Kantor Sistem Administrasi Manunggal Satu Atap Unit Pelaksana Teknis Daerah Kota Manado. Kondisi rell yang diperoleh dari data keluhan atas pelayanan sehubungan dengan kecepatan pelayanan, keamanan pelayanan, pelayanan yang murah dan ramah menunjukkan bahwa ke lima hal tersebut belum dapat diwujudkan oleh pegawai yang dipercayakan untuk melayanan masyarakat dalam pelayanan pajak kendaraan bermotor baik roda dua maupun roda empat.

Permasalahan atas keluhan pelayanan pada kecepatan waktu pelayanan. Selain keluhan atas waktu pelayanan, kondisi keamaman atas pelayan juga menjadi hal yang cukup serius diperhatikan pada pelayanan pajak kendaraan bermotor. Keamanan pelayanan berkaitan dengan petugas atau pegawai yang ditugaskan di loket pelayanan, nota pajak, surat tanda nomor kendaraan yang diterima, buku pemilik kendaraan bermotor yang diterima dan lain sebagainya. Keluhan lainnya juga terlihat dari masalah kepastian biaya dan kewajaran sekalipun yang disampaikan oleh petugas kolektor penetapan pajak bahwa yang harus dibayarkan sesuai dengan yang terhitung sebagaimana peraturan yang berlaku dan harus dibayar ke loket pembayaran akan tetapi ada juga pegawai yang menerima pembayaran untuk diteruskan kepada petugas pembayaran.

Berbagai perilaku yang ditunjukan dari sikap dan tindakan pegawai yang menjadi keluhan masyarakat sebagai akibat dari pengembangan kinerja pegawai yang belum didesain sesuai dengan visi dan misi organisasi dan lebih menekankan pada terwujudnya Pendapatan Asli Daerah sebagai sumber utama Anggaran Pendapatan Belanja Daerah bukan pada pelayanan. Pengembangan kinerja pegawai perlu dilakukan dengan cara melakukan perbaikan pada menyusun rencana, tindakan pelaksanaan, pengawasan jalannya dan hasil pekerjaan, evaluasi atas jalannya pelaksanaan (kemajuan serta kegagalan yang ada), sistem karier, kompetensi, kompensasi dan motivasi kerja. Sebab banyak pegawai akhirnya tidak memiliki komitmen yang tinggi dalam penyelesaian keluhan karena merasa jenuh dengan pekerjaan dan sistem kerja, tidak memiliki motivasi prestasi, dan lain sebagainya.

Komitmen dapat dipahami sebagai kemauan dan penerimaan seseorang dalam bertindak. Seorang pegawai yang memeliki kemauan untuk bekerja keras berkaitan dengan sasaran-sasaran dan nilai-nilai tertentu. Komitmen yang baik dalam memberikan pelayanan maupun dalam memperbaiki pelayanan sebagai respon positif atas keluhan yang ada terwujud dalam kesungguhan petugas dalam memberikan pelayanan, terutama terhadap konsistensi waktu kerja sesuai ketentuan yang berlaku. Berkaitan dengan dimensi keandalan pada pelayanan publik sebagaimana Parasutaman dalam Tjiptono (1997), yaitu kemampuan memberikan pelayanan yang dijanjikan dengan segera, akurat dan memuaskan. Olehnya petugas pelayanan harus siap dan sesuai dengan atura dalam melayani sehingga proses pelayanan dapat berjalan sesuai target waktu yang ditentukan. 
Robbins dan Judge (2009), mengemukakan bahwa komitmen organisasional adalah tingkat sejauh mana seorang karyawan memihak sebuah organisasi serta tujuan-tujuan dan keinginannya untuk mempertahankan keanggotaan dalam organisasi tersebut. Keterlibatan terhadap pekerjaan yang tinggi berarti memihak kepada pekerjaan tertentu oleh seseorang/individu, sementara komitmen organisasional yang berarti memihak kepada organisasi, merupakan tempat yang mewadahi individu tersebut melakukan suatu pekerjaan.

Untuk membentuk komitmen dalam melayani masyarakat dengan semangat dan kemauan yang tinggi tentunya melibatkan emosional pegawai tersebut. McShane and Glinow (2008:119), mereka mengatakan bahwa "Organizational commitment refers to the employee's emotional attachment to, identification with, and involvement in a particular organization”. Emosi atau perasaan yang dialami seseorang pada organisasi dapat terjadi jika pegawai tersebut terlibat secara aktif dalam kerja-kerja, program-program serta target yang ditetapkan dalam organisasi yang melibatkan pegawai sebagai bagian yang tak terpisahkan dalam suatu sistem organisasi. Maka pegawai akan mempunyai rasa saling memiliki dan menerima kesamaan dan perbedaan antara mereka yang dalam hal ini keterlibatan ini dalam pelayanan pajak kendaraan bemotor melalui prosedur pelayanan yang diberikan.

Komitmen yang tinggi dari pegawai dalam menjadikan pelayanan penting bagi organisasi, karena dengan komitmen yang tinggi pegawai akan bersikap profesional dan menjunjung nilai-nilai yang telah disepakati bersama dalam organisasi, yang fokusnya adalah nilai-nilai dan sikap yang dimiliki oleh pegawai. Keberhasilan dalam penyelenggaraan kerja tidak dapat dipisahkan dari kontribusi atas komitmen pegawai menjadikan Kantor Sistem Administrasi Manunggal Satu Atap Unit Pelaksana Teknis Daerah Kota Manado mampu menerapkan tujuan dalam mensejahtrakan pegawai sebagaiman tujuan ke lima dari kantor dalam penjabaran misi Dinas Pendapatan Provinsi Sulawesi Utara yaitu kesejahteraan yang dipahami bahwa nilai organisasi mengedepankan kesejahteraan pegawai dan keluarga. Sangat berkaitan dengan kinerja dinas, dimana pegawai yang sejahtera dapat diharapkan memperoleh kinerja yang baik dan sebaliknya dari pegawai yang tidak sejahtera sulit diharapkan hasil kerja yang baik.

Untuk menujudkan komitmen pegawai yang tinggi dalam meresponi berbagai keluhan yang ada setidaknya Kantor Sistem Administrasi Manunggal Satu Atap Unit Pelaksana Teknis Daerah Kota Manado perlu memperhatikan pengembangan kinerja pegawai dengan perlu dirancang sesuai dengan visi dan misi organisasi. Disamping itu partisipasi individu secara aktif dan mandiri menjadi dinamika utamanya, sehingga kekompakan kerja dalam unit, atau kelompok kecil, dapat tercapai. Jika pegawai berpartisipasi secara penuh dalam bekerja berarti pegawai memperhatikan kepentingan-kepentingan organisasi dalam mencapai tujuan- tujuannya. Pegawai menjadi lebih peduli terhadap fungsi organisasi yang efektif, sehingga lebih loyal dan berdedikasi dalam melakukan pekerjaan, serta berusaha memelihara perilaku-perilaku yang dimilikinya dalam melakukan tugas pekerjaan tersebut.

Pegawai tersebut akan lebih berkomitmen dalam bekerja, karena mereka memandang usaha dan kinerja yang mereka berikan terhadap organisasi memiliki makna yang positif bagi kesejahteraan organisasi dan kesejahteraan individu mereka. Sependapat dengan hal tersebut, Whitmore, (1996), mengemukakan bahwa tanggung jawab dan partisipasi yang menyeluruh dapat dianggap sebagai kadar yang menunjukkan sejauh mana komitmen organisasi secara keseluruhan merupakan bagian penting dalam kehidupannya. Perilaku produktif merupakan konsekuensi dari adanya suatu tanggung jawab dari pegawai untuk mencapai kinerja yang tinggi melalui cara-cara kerja yang efektif dan efisien. Hal ini menjadikan pegawai mau mengerahkan tenaga, pikiran, dan potensinya serta berpartisipasi secara penuh untuk mencapai tujuan organisasi.

Komitmen dalam memperbaiki kerja sebagai akibat dari adanya keluhan atas pelayanan pajak kendaraan bermotor menjadikan pegawai yang ada di Kantor Sistem Administrasi Manunggal Satu Atap Unit Pelaksana Teknis Daerah Kota Manado memiliki keinginan atau kemauan yang kuat untuk bekerja dengan keterlibatan-keterlibatan nyata menurut pekerjaan yang ditekun berdasarkan tugas dan fungsi yang melekat pada jabatan dengan penuh rasa tanggung jawab terhadap aktifitas-aktifitas organisasi. Komitmen akan nyata dalam aktivitas kerja melalui keterlibatan pegawai dalam organisasi sebagai bentuk loyalitas kepada pemerintah dan masyarakat yang terlihat dari kejujuran dalam pekerjaan, perhatian dan kepedulian dan kepercayaan. Oleh karenannya Komitmen dalam organisasi harus diusahakan untuk dapat ditingkatkan.

Robbins,(2009) berpendapat bahwa ciriciri individu dengan komitmen organisasi yang tinggi, ditunjukkan dengan tingginya loyalitas dan dedikasi terhadap organisasi. Hal ini menjelaskan bahwa pegawai akan melakukan segala cara agar organisasi mampu mencapai sukses. Oleh karenanya kejujuran dalam pekerjaan, perhatian, kepedulian dan kepercayaan terhadap pegawai, perbedaan karakteristik individu (usia, tingkat pendidikan, jenis kelamin, status perkawinan, karakteristik yang berhubungan dengan pekerjaan, karakteristik struktural (formalitas, desentralisasi), pengalaman dalam kerja, kepercayaan dan penerimaan yang penuh atas nilai-nilai dan tujuan organisasi, keinginan bekerja keras demi kepentingan organisasi, dan keinginan untuk mempertahankan diri agar tetap menjadi anggota organisasi.

Dan untuk membangun komitmen McShane and Glinow (2008:120) mengemukakan beberapa cara yaitu keadilan dan dorongan, kepercayaan, organisasi secara keseluruhan, keterlibatan karyawan 
dan kepercayaan karyawan. Melalui hal ini setidaknya masyarakan yang mengeluhkan pelayanan yang dirasakan akan merasa bahwa suara mereka didengar. Sehingga segala bentuk keluhan atas pelayanan yang dilayangkan akan dapat menjadikan Kantor Sistem Administrasi Manunggal Satu Atap Unit Pelaksana Teknis Daerah Kota Manado memperkuat dan mengkomunikasikan nilai-nilai dasar, sikap dan tujuan organisasi dalam perilaku kerja yang lebih baik.

Oleh karena itu, orientasi pelayanan harus berubah dari sekedar memenuhi kebutuhan pengguna jasa kearah pelayanan yang memuaskan pengguna jasa disertai dengan perilaku pelayanan secara tulus. Untuk dapat mencapai taraf pelayanan seperti ini, aparat tidak hanya dituntut harus menguasai teknik pelayanan tetapi juga harus memiliki kesadaran emosional agar tercapai pelayanan yang memuaskan dan sepenuh hati sesuai dengan standard pelayanan yang berkualitas. Sehingga pelayanan publik yang berkualitas dapat di capai melalui penyelenggaraan pelayanan publik yang diberikan oleh Kantor Sistem Administrasi Manunggal Satu Atap Unit Pelaksana Teknis Daerah Kota Manado yang dapat memuaskan masyarakat sebagai penerima pelayanan.

\section{SIMPULAN}

Berdasarkan hasil penelitian dan pembahasan maka kesimpulan penelitian ini bahwa komitmen penanganan keluhan belum sepenuhnya nyata dijalankan pada pelayanan pajak kendaraan bermotor di Kantor Sistem Administrasi Manunggal Satu Atap Unit Pelaksana Teknis Daerah Kota Manado karena pengembangan kinerja pegawai lebih menekankan pada terwujudnya Pendapatan Asli Daerah sebagai sumber utama Anggaran Pendapatan Belanja Daerah bukan pada peningkatan kualitas pelayanan.

Olehnya komitmen penanganan keluhan perlu dilakukan dengan cara perbaikan pada pengembangan kinerja pegawai yang mencakup perbaikan pada menyusun visi, misi dan rencana organisasi, tindakan pelaksanaan, pengawasan jalannya dan hasil pekerjaan, evaluasi atas kemajuan serta kegagalan organisasi, sistem karier, kompetensi, kompensasi dan motivasi kerja. Serta perlu dilakukan perbaikan pada pembenahan sarana dan fasilitas pelayanan dan melakukan proteksi terhadap produk-produk layanan, menempakan petugas yang secara khusus hanya menangani keluhan masyarakat dan menyediakan sistem penanganan keluhan pelayanan pajak kendaraan bermotor yang berbasis elektronik.

\section{DAFTAR PUSTAKA}

Boshoff, C, and Gerhard, M. 1995. "Reveals that the Organizational Commitment of Insurance salespeople exert a strong”. European Journal of Marketting, Vol. 29, issue 2, pp. 23-42.

Gorton. M. 2005. Guide to Complaint Handling In Health Service Care. Victoria : William Troedel \& Co Pty Ltd.

Heinsman, H. Annebel, H.B., Hoogh, D. and Koopman, P.L. 2008, "Commitment, control, and the use of competency management", Department of Work and Organizational Psychology, Personnel Review Vol. 37 No. 6, pp. 609-628.

Herman, D, 2005, "Pengaruh Budaya Organisasi dan Komitmen Organisasi Terhadap Karyawan ", PT Bintang Timur Surabaya, Tesis, Universitas Airlangga, Surabaya.

LAN RI, 2006. Manajemen Pelayanan Publik, Jakarta: LAN RI

Luthans, F. 2008. Organizational Behavior eleventh Editions. Mc Graw Hill/Irwin.

McShane, S.L. dan Glinow, M.A.v. 2008. Organization Bahavior Fourth edition. New York : McGrawHill International.

Robbins, S.P., and Judge, T.A. 2009, Organizational Behavior. United State Of America, New York: Pearson Prentice Hall.

Tjiptono, F. 1997. Total Quality Service.Yogyakarta: Andi.

Undang-Undang Republik Indonesia Nomor 25 Tahun 2009 tentang Pelayanan Publik 